\title{
Behavioral Economics and Perverse Effects of the Welfare State
}

\author{
Scott Beaulier and Bryan Caplan*
}

\begin{abstract}
The most compelling explanation for the marked shift in the fortunes of the poor is that they continued to respond, as they always had, to the world as they found it, but that we-meaning the not-poor and un-disadvantaged - had changed the rules of their world. Not of our world, just of theirs. The first effect of the new rules was to make it profitable for the poor to behave in the short term in ways that were destructive in the long term. Their second effect was to mask these longterm losses - to subsidize irretrievable mistakes. We tried to provide more for the poor and produced more poor instead. We tried to remove the barriers to escape from poverty, and inadvertently built a trap.
\end{abstract}

(Charles Murray, Losing Ground, p. 9)

\section{INTRODUCTION}

A recurring criticism of the welfare state is that it perversely harms the very people it is intended to help ${ }^{1}$. Giving money to the poor reduces their incentive to enter the workforce, acquire experience, and eventually join the middle class. Providing welfare support for children born out-of-wedlock encourages teen pregnancy and discourages marriage, two serious impediments to escaping poverty (Herrnstein and Murray 1994, Murray 1984). As Murray Rothbard succinctly puts it, '[T]he easy availability of the welfare check obviously promotes present-mindedness, unwillingness to work, and irresponsibility among the recipients - thus perpetuating the vicious cycle of poverty-welfare' (1978, p. 154).

* Scott Beaulier, Assistant Professor, Department of Economics and Management, Beloit College, Beloit, WI 53511. Email: beaulies@beloit.edu. Bryan Caplan, Associate Professor, Department of Economics and Center for Study of Public Choice, George Mason University, Fairfax, VA 22030. Email: bcaplan@gmu.edu.

We would like to thank Tyler Cowen, Robin Hanson, Kevin McCabe, Dan Houser, Ron Heiner, seminar participants at George Mason University, Beloit College and New York University and an anonymous referee for discussion and comments. The standard disclaimer applies.

1. Murray (1984) is arguably the most prominent critic of the 'War on Poverty.' Friedman (1982 [1962]) offered similar arguments against public housing and welfare two decades earlier: the goal of these programs was to help the poor, but the unintended effect was 'just the reverse' (179). Sowell (1996 [1980], 1990) and Chavez $(2002,1992)$ raise similar objections to affirmative action and related policies. 
There is a parallel complaint about affirmative action in higher education: It allegedly leads minority students to enroll in overly competitive programs. In consequence, students able to earn a college degree from a less competitive school often wind up dropping out and fail to complete any degree at all. As Thomas Sowell critically observes:

This [minority] student does not get a better education because he is at a more prestigious school. On the contrary, he may well get a much worse education at such fast-paced institutions, in the sense of failing to learn things which he is perfectly capable of learning, in a learning environment that proceeds at a normal pace. Such a minority student may end up 'confused, floundering, and unable to keep up.' (1993, p. 137)

Whatever the intuitive appeal of these sorts of arguments, they are difficult to rationalize with standard microeconomic theory. To be more precise, textbook analysis suggests that each of the preceding claims is half right and half wrong. Yes, giving money to the poor reduces their incentive to enter the workforce, acquire experience, and eventually join the middle class through their own efforts. But this hardly shows that it makes the poor worse off! All the transfer program does is make the non-work option more attractive. If it remains less attractive than work, the poor will still opt for work. If, on the other hand, the poor decide to take the government's money and remain idle, it must be because - all things considered - it maximizes their expected lifetime utility. In other words, if you were to remind welfare recipients that they are hurting their future job prospects, they could curtly respond: 'I am well-aware of that, but my welfare checks more than compensate for my loss of future income.' As Tyler Cowen explains, the 'traditional conservative critique of the welfare state ...'

... involves an analytic tension. In most matters, conservatives and libertarians argue from neoclassical and Chicago school economic theories. In these approaches, a gift of cash always makes individuals better off, as evidenced by the classroom demonstration of how such gifts shift individuals onto 'higher indifference curves.' This is a basic lesson of any intermediate course in microeconomics, regardless of the political persuasion of the instructor. (2002, p. 39)

The same goes for any government program that expands the opportunity set of the poor. It may very well change their behavior, but elementary micro tells us that if you make a different choice after your opportunity set expands, your utility must rise. If affirmative action gives under-qualified minority students the chance to attend an Ivy League school, they are better off if they take advantage of this offer, and no worse off if they refuse.

Of course, this is only true ex ante; agents might come to regret a choice as events unfold. But the standard assumption of basic microeconomics is that agents' expectations are, on average, correct. If some welfare recipients underestimate the adverse effects on their future job prospects, there are others 
who overestimate them. Thus, for every person who mistakenly goes on welfare, there is another potential welfare recipient who, contrary to his own best interests, insists on pulling his own weight.

Microeconomic theory emphasizes, moreover, that choices with immediate benefits and long-run costs are still made optimally. If a teenage girl decides to have an out-of-wedlock child and go on welfare, it is because she has determined that the up-front benefits of the child and the government's financial assistance outweigh the long-run costs of foregone earnings and diminished marriage prospects. Basic micro is a one-size-fits-all theory of choice: Trade-offs between two immediate benefits are of one cloth with tradeoffs between immediate and more distant benefits.

Within the confines of standard microeconomics, then, many claims about the welfare state's perverse effects cannot be sustained. Rather than reject these claims as incoherent, however, the current paper argues that we should rethink them using the tools of behavioral economics (Kahneman, Slovic, and Tversky 1982, Thaler 1992, Rabin 1998, Sunstein 2000). This large and growing literature casts a degree of empirical doubt on even the most elementary principles of microeconomics. It strongly undermines, for example, the rational expectations account of belief formation, uncovering an array of systematic errors in the thinking of the average subject (Rabin 1998). It also uncovers a variety of intertemporal anomalies, such as self-control problems (O'Donoghue and Rabin 1999a, 1999b, Kirby and Herrnstein 1995, Akerlof 1991, Thaler and Shefrin 1981).

The perverse effects frequently attributed to the welfare state are easy to interpret from a behavioral perspective. If people overestimate the magnitude of immediate benefits relative to more distant ones, you can actually - on net harm them by offering them additional immediate benefits. They already tend to under-invest. Making their present more livable with cash gifts only amplifies this tendency. Similarly, if individuals systematically overestimate their own abilities, you could easily harm a student by admitting him to a program for which he is under-qualified. Blinded by over-confidence, he would be likely to select the best school that accepted him, scarcely considering the possibility that he will be out of his league.

Looking at the welfare state from a behavioral standpoint lays the groundwork for a stronger claim: Potential welfare recipients' deviations from neoclassical assumptions tend to be especially pronounced. If the average American falls short of the neoclassical ideal, the average recipient of government assistance does not even come close.

To justify this generalization, we draw on the large literature on "pathological' behavior among the poor. Many pathologies can be readily understood as extreme versions of the anomalies emphasized in the behavioral literature. The experimental literature finds, for example, that the average experimental 
subject underestimates future costs of immediate satisfaction; and even when they recognize these costs, self-control problems may keep them from changing their behavior (Thaler 1992). But the average experimental subject's deviations seem mild compared to those typical of the poor. Many activities - from overeating, drinking, smoking, and drug abuse to crime and unprotected sex combine immediate gratification with delayed costs. We argue that it is no coincidence that the poor are much more prone to engage in such activities than the rest of the population.

Thus, behavioral economics can reinvigorate arguments about the perverse effects of the welfare state in two distinct ways. For starters, we need behavioral economics to make this critique coherent. Once they have been explicitly placed on a behavioral foundation, claims about the perverse effects of various programs become harder to ignore or dismiss. More importantly, there are good empirical reasons to think that behavioral economics better describes the poor than it does the rest of the population. Behavioral economics is therefore exceptionally relevant to poverty policy.

The paper is structured as follows. Section II discusses previous literature on the perverse effects of the welfare state, highlighting its theoretical weaknesses. Section III shows how a variety of findings from behavioral economics put what Cowen calls the 'traditional conservative critique' of the welfare state in a new and favorable light. Section IV presents evidence that behavioral economics offers considerably more insight into potential welfare recipients than it does for the rest of the population. Section $\mathrm{V}$ explores the counter-intuitive policy implications of our analysis. Section VI concludes.

\section{PERVERSE EFFECTS OF THE WELFARE STATE?}

Many claims about the negative impact of government policies on the poor can be readily parsed in neoclassical terms. To take a standard example, the rich live longer than the poor, and start work later in life, so the gross benefit the poor receive from Social Security and Medicare is relatively small. Since payroll taxes are regressive, the net benefit of Social Security for the poor might turn out to be negative. Similarly, even if the poor receive twice as many dollars in government medical care as they pay in taxes to fund such programs, they are still worse off if they value a dollar's worth of medical care at less than fifty cents. Arguments against the minimum wage and rent control fit the same pattern: the benefits of higher wages or lower rents could easily be less than the expected costs of rationing. This is straight out of the textbook.

Less direct complaints about how policy hurts the poor can be rationalized in neoclassical terms as externalities. One poor family will be better off if it takes government assistance. But its members can be worse off on balance because 
other families in their area participate in the same program. Their neighborhood becomes a worse place to live as the mix of local activity shifts from productive work to drug use or crime. There could also be intra-family externalities. A father willing to support his family might abandon it if the government will assume his responsibilities. The father is better off as a result of the government program, but his wife and family are worse off if they prefer the presence of a working father to a stream of government checks.

This paper focuses on a third, quite different, category of arguments. These make the dramatic claim that government gifts by themselves make their recipients worse off. The simplest version is that by giving the poor material support, we discourage them from getting jobs, acquiring experience, and eventually pulling themselves up by their bootstraps. In Sowell's words, 'For young workers especially, the things you can learn on ["menial"] jobs responsibility, cooperation, punctuality - can be lifelong assets in many other occupations. Insulating people from such realities is one of the many cruelties perpetuated under the banner of "compassion"' (1987, p. 36). What appears to be altruistic assistance makes the recipient worse off by making him unemployable in the future.

In the simplest model of choice under certainty, this argument is in direct conflict with revealed preference (Figure 1). No one is forced to take the money. If the future sacrifices outweigh the present benefit, the prospective welfare

Figure 1

Neoclassical Effect of Welfare

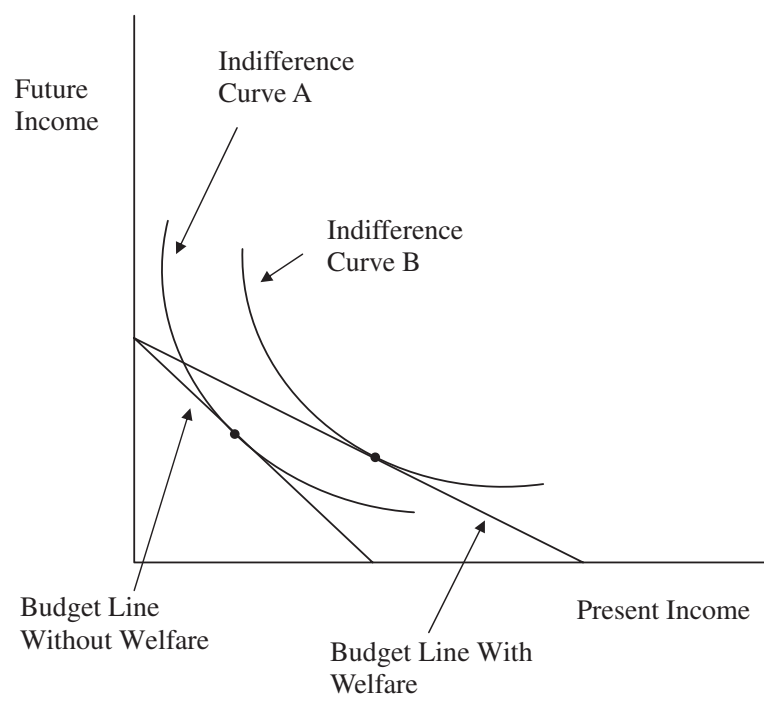


recipient can simply turn the money down. An extra option must weakly increase his utility. Adding uncertainty admittedly opens up the possibility that you select a newly available option that works out badly for you. But here the familiar distinction between ex post and ex ante utility comes into play. We can reconceptualize agents as choosing gambles instead of outcomes. Then putting an extra choice on your menu of gambles must weakly increase your expected utility.

Of course, if your expectations are completely at odds with the facts, this result is far weaker than it sounds. Standard neoclassical practice, though, is to assume rational expectations (Sheffrin 1996, Pesaran 1987). By implication, the probabilities that agents assign to outcomes are, on average, correct. So when agents expect to benefit by selecting a new option, on average they really do benefit.

In sum, there are three main families of criticism of the welfare state. One is that the poor sometimes pay more in taxes than they get in benefits; another appeals to inter- or intra-family externalities. These are not the subject of our paper. We focus our attention on a third family of criticism, which blames government for somehow leading its 'beneficiaries' astray. Arguments of this form are rhetorically persuasive in spite of their incompatibility with basic micro. Is there any way to make sense of them?

\section{A BEHAVIORAL RETHINKING OF THE TRADITIONAL CONSERVATIVE CRITIQUE}

Indeed there is. The voluminous behavioral literature subjects the fundamental propositions of textbook microeconomics to extensive empirical tests, and documents a wide variety of exceptions. It also offers alternative theories of human behavior to accommodate the empirical findings (Kahneman and Tversky 1979, Kahneman et al. 1990, Laibson 1997, Camerer and Thaler 1995).

Yet in spite of the maturity of the behavioral economics literature, behavioral economics has almost never been used to rethink welfare policy ${ }^{2}$. This is unfortunate because behavioral economics offers a novel perspective in this much-debated area. There are two main avenues we would here like to explore ${ }^{3}$. The first is judgmental biases. The second is self-control problems.

2. Bertrand, Mullainathan, and Shafir (2004) is the only exception of which we are aware. Akerlof's (2002, p. 412) discussion of the 'stubborn persistence of a self-destructive underclass' is broadly in the spirit of the current paper, but he focuses on a novel explanation ('the economics of identity') instead of turning to the pre-existing behavioral literature. Glaeser (2006), building on Frey and Eichenberger (1994, 1989a, 1989b) uses behavioral political economy to question the value of paternalist policies, but does not specifically discuss welfare policy.

3. We do not intend this to be a comprehensive examination of the links between behavioral economics and welfare policy. Our goal is to highlight the connections we expect to be most fruitful. 


\subsection{Judgmental Biases}

Judgmental biases are tendencies to hold systematically mistaken beliefs, beliefs predictably at odds with established empirical facts or with principles of logic, mathematics, or statistics. (Kahneman and Tversky 1982, p. 493). Out of the large literature on such biases, two stand out for our purposes: selfserving bias and biased risk estimates.

A recurring finding in behavioral economics is that people 'tend to be both unrealistically optimistic and overconfident about their judgments' (Sunstein 2000, p. 8). They suffer, in short, from 'self-serving bias.' More than half of survey respondents rate themselves in the top 50 percent of health, ethics, driving ability, life expectancy, and labor productivity (Taylor 1989, Weinstein 1989) - a mathematical impossibility. What is particularly interesting, though, is that mistakes tilt in the direction of positive self-image. This goes directly against the standard rational expectations assumption.

Similarly, individuals make biased risk estimates. Viscusi $(1996,1992,1987)$ finds that individuals put too much emphasis on small risks and not enough on large ones. Individuals are overly concerned with highly publicized events (such as poisons in their food and water or anthrax contamination) but take much greater hazards for granted ${ }^{4}$. Thaler and Johnson (1990) similarly find that racetrack bettors suffer from 'longshot bias': bettors overestimate the chance that the longshot horse will win.

What do these behavioral findings have to do with the poor? Take the case of single mothers. On the road to single motherhood, there are many points where judgmental biases plausibly play a role. At the outset, women may underestimate their probability of pregnancy from unprotected sex. After becoming pregnant, they might underestimate the difficulty of raising a child on one's own, or overestimate the ease of juggling family and career. Policies that make it easier to become a single mother may perversely lead more women to make a choice they are going to regret.

A simple numerical example can illustrate the link between helping the poor and harming them. Suppose that in the absence of government assistance, the true net benefit of having a child out-of-wedlock is $-\$ 25,000$, but a teenage girl with self-serving bias believes it is only $-\$ 5000$. Since she still sees the net benefits as negative she chooses to wait. But suppose the government offers $\$ 10,000$ in assistance to unwed mothers. Then the perceived benefits rise to $\$ 5000$, the teenage girl opts to have the baby, and ex post experiences a net benefit of $-\$ 25,000+\$ 10,000=-\$ 15,000^{5}$.

4. For a contrasting view, see Benjamin and Dougan (2001, 1997).

5. In the discrete case, of course, you can eventually make the recipient better off with a large enough gift (in this example, a gift greater than $\$ 25,000$ ). With continuous choices, though, even an unlimited 
Or take another scenario: affirmative action in higher education. Could giving minority students more choices make them worse off? It could if they are unrealistically optimistic about their probability of success, leading them to choose an opportunity beyond their capabilities. Self-serving bias might also incline each student to assume that he was admitted on his own merits: 'If I were being admitted because of affirmative action, I should be worried. But unlike many other students, $I$ was accepted on my merits.'

\subsection{Self-Control Problems}

Ethnographic writers often emphasize that the poor, to put it bluntly, are lazy and short-sighted (Haley and X 1999 [1964], p. 275, 318, Wilson 1996, p. 118). But there is no need to turn to behavioral economics to understand this. Neoclassical theory certainly allows for agents to have high disutility of work (i.e., to be 'lazy') and high discount rates (i.e., to be 'short-sighted'). The logic of neoclassical welfare economics still applies to those at the extreme tails of the preference distribution: expanding the opportunity set of the lazy and shortsighted makes them subjectively better off. If a person has a genuine hatred for work, a cash gift may enable him to leave the labor force as he always dreamed of doing. If a person is extremely impatient, similarly, he is better off overall if a government program subsidizes front-loaded consumption. Under these circumstances, limiting the safety net can be a benefit for taxpayers, but not recipients.

Behavioral economists have studied a superficially similar set of choice anomalies distinct from laziness and short-sightedness: self-control problems. People often speak about failing to lose weight, struggling to quit smoking, or procrastinating on a term paper. There appears to be a conflict with traditional choice theory: An agent should either smoke (if the benefits exceed the costs) or not smoke (if the costs exceed the benefits). Why would the decision be tortured and vacillating? (O'Donoghue and Rabin 2003). For some, apparently, it is a battle - and often a losing one - to maximize expected lifetime utility.

How precisely do self-control problems differ from disutility of work or high discount rates? A person lacking in self-control predictably regrets his choices. After he makes them, he wishes he had done something else. Indeed, even as he makes one choice, in some sense he might prefer to do something else ${ }^{6}$. Laibson

budget may not suffice. For example, if a heroin addict spends $100 \%$ of his income on heroin, and each dose of heroin on net makes him worse off, then his utility is strictly decreasing in income.

6. Thus, problems of self-control are distinct from judgmental biases. A person can have rational expectations about the actual consequences of his actions, but still internally struggle to take the action he deems optimal. 
et al. (1998, p. 95) point to the conflict between 'attitudes, intentions, and behavior.' When a neoclassical actor with a high discount rate ignores long-run consequences, it is not a difficult decision. Unlike an agent with a self-control problem, he does not regret his choice or repeatedly pledge to change his life. You might say that a self-control problem is akin to having intransitive preferences - or more accurately, irreflexive preferences. In some sense, the procrastinating student prefers partying to studying, but the opposite preference is also present. Or to take a topic of far greater policy significance, behavioral evidence on self-control has also often been used to criticize the optimality of retirement planning. As Laibson et al. put it:

[C]onsumers face two challenges: making good decisions and sticking to them. Economists have adopted optimistic assumptions on both counts. The consumers in mainstream economic models are assumed both to be exceptionally good decisionmakers and to be able to carry out their plans. These economic assumptions are dubious, particularly in regard to saving for retirement. (1998, p. 92)

When an agent has self-control problems, traditional welfare analysis is problematic. Is a smoker who wants to quit better off if he throws all of his tobacco away? What if a fellow smoker tempts him by offering him a cigarette? At any given moment, he prefers to light up and inhale. But at the beginning of each day, he prefers to be a non-smoker.

Given self-control problems, policies that help an agent realize his momentary goals can derail his effort to achieve his meta-goals. It is possible, then, that expanding an agent's opportunity set makes him worse off ${ }^{7}$. This is particularly clear if we affirm that the meta-goals are the 'true' arguments in agents' utility functions. Behavioral economists often implicitly take this stance. Even if we remain agnostic about the priority of meta-goals over momentary ones, though, the existence of self-control problems undermines the certainty of neoclassical welfare economics. Giving your obese neoclassical friend a big box of chocolates cannot make him worse off; but it is at least possible your obese behavioral friend would be better off without your delicious present.

What do self-control problems have to do with the problems of the poor? Returning to an earlier example, the choice to have unprotected sex is a classic case where agents experience inner conflict. The immediate benefits are so enticing, but what about the enormous long-run costs? A neoclassical agent with high time preference will happily choose the immediate benefit. But realworld agents might not only predictably regret having unprotected sex, but regret it even at the time.

7. See for example Cutler, Glaeser, and Shapiro (2003), which considers the possibility that due to selfcontrol problems, lower costs of food preparation have on net harmed Americans by increasing obesity. 
Self-control problems could also easily amplify the perverse effects of affirmative action. After doing poorly in an overly competitive university, a minority student has to decide whether to redouble his efforts or drop out. Following a string of setbacks, dropping out has immediate benefits - escaping academic stress and personal dejection - but the costs in terms of foregone earnings take years to materialize. Students with self-control problems will tend to take the easy way out - and regret it.

The literature on self-control also suggests that 'laziness' may not be the best way to explain the difficulty the poor have holding down a job. Instead, they may simply lack self-control. If one's current job is somehow unpleasant, quitting is an easy way out. But there are long-term costs of running away from your problems: each quit makes you less attractive to future employers. A neoclassical agent would optimally balance these concerns. An agent with selfcontrol issues might repeatedly give in to the temptation to quit until he becomes almost unemployable ${ }^{8}$.

\section{THE POOR DEVIATE MORE}

Behavioral economics tells us that individuals have judgmental biases and suffer from self-control problems. Giving a person more choices therefore has the potential, contrary to basic microeconomics, of predictably making that person worse off. From this general principle, we can deduce that when government assistance expands the choice sets of the disadvantaged, it can make recipients worse off. In other words, behavioral economics provides a 'possibility theorem' for welfare policy: expanding opportunity sets may backfire.

At minimum, then, this counsels against summarily dismissing theories about the welfare state's perverse effects. But we can go further. Existing literature provides good reasons to think that the deviations of the poor from the standard neoclassical model are especially pronounced. Their judgmental biases are more extreme, and their self-control problems more severe, than those of the rest of the population. Standard neoclassical theory is unusually likely to mislead us when we analyze policies intended to assist the disadvantaged.

8. Wilson's (1996, p. 120) interviews with inner-city employers about employee turnover nicely capture this danger:

'... they'll, on the application itself, just say something like 'didn't get along with supervisor' and then the next job, reason for leaving, 'didn't get along with supervisor,' next job reason for leaving, 'didn't like it,' and they'll have gone through three or four jobs in a matter of six or eight months and then they don't understand why they don't get hired here.' 


\subsection{Quantitative Evidence}

Behavioral economists frequently highlight certain kinds of behavior - like over-eating, drinking, smoking, drug use, and retirement planning - to make their case. It is not hard to lengthen the list to include crime, unprotected sex, and other traditional 'social pathologies.' What is rarely emphasized in the behavioral literature, though, is that deviant behavior is much more pronounced among the poor.

Take drinking. The Substance Abuse and Mental Health Services Administration (1997) finds that ' 9.4 percent of workers in the $\$ 9,000$ $\$ 19,999$ income group reported heavy alcohol use, while only 2.1 percent of workers in the highest income bracket $(\$ 75,000$ and more) reported heavy alcohol use.'

Or consider obesity. Cutler, Glaeser, and Shapiro (2003, p. 97) report that obesity generally declines markedly as education rises. During 1971-75 period, this was true for both genders: $24 \%$ of women and $15 \%$ of men without high school diplomas were obese, versus $7 \%$ of women and $8 \%$ of men with college degrees. In the 1988-94 period, 38\% of women with less than high school educations were obese, versus $20 \%$ with college degrees. (Male obesity rates however no longer show a substantial educational pattern.) Given the strong correlation between education and income, there is little doubt that the poor have more trouble maintaining a healthy body weight.

Parallel results holds when we examine smoking and drug use. According to the National Household Survey on Drug Abuse (2002):

\footnotetext{
... 35 percent of persons with total combined family incomes of less than $\$ 9,000$ reported smoking cigarettes during the past month compared with 29 percent of those from families with incomes between $\$ 20,000$ and $\$ 39,999$ and 19 percent of those from families with incomes of $\$ 75,000$ or more.
}

Similarly:

an estimated 15.4 percent of unemployed adults (aged 18 and older) were current illicit drug users in 2000, compared to 6.3 percent of full-time employed adults and 7.8 percent of part-time employed adults using illicit drugs.

Recent sociological work confirms that the poor also deviate more in their sexual behavior. Manlove et al. (2000) report that risk of birth throughout adolescence is decreasing in income. Similarly, controlling for family background, Sucoff and Upchurch (1998) found that black teenagers living in 'underclass' and 'working class' neighborhoods were more likely to have sex at earlier ages and more likely to give birth as teenagers. The National Survey of Family Growth (1996) reports that out-of-wedlock births occur far more frequently among the poor - only one in seven unmarried mothers have 
incomes above $\$ 25,000$; four out of every ten unmarried mothers have incomes below $\$ 10,000$.

To take a final social pathology, the poor are also prone to criminal behavior - a 'career option' notorious for its fleeting benefits and long-run costs. A Special Report of the Bureau of Justice Statistics (Harlow 1998, p. 4), to take only one example, explains that 'Jail inmates reported low incomes. Almost half reported incomes of less than $\$ 600$ a month - at most $\$ 7,200$ annually - in the month before their most recent arrest.' It is tempting to assume that criminals turn to crime because of their low earnings, but only $15 \%$ of the inmates reported receiving illegal income. Some of the most common offensesincluding assault, drug possession, and drunk driving - are rarely lucrative. Indeed, as Levitt and Dubner (2006, pp. 79-104) document, even crime that pays rarely pays well; despite occupational risks, drug dealers often earn about the minimum wage. Objectively speaking, crime is an ineffective way to escape poverty. But it is easy to see the appeal of crime to those who overestimate their chance of becoming a gang leader, or who simply have poor impulse control.

One could try to minimize this evidence. Yes, the poor have a higher average incidence of pathological behavior, but the deviation is only in the tails, not the median. The absolute level typically remains far below $50 \%$. In the behavioral literature, however, serious problems are normally seen as extreme manifestations of continuous tendencies. From this standpoint, if you see a sub-population with higher level of extreme behavior at the tails, you should also infer a higher median. Extreme behavior is only the tip of the iceberg; the more you see above the water line, the more you can infer lies beneath it ${ }^{9}$.

\subsection{Accounting for the Deviation}

Why would the poor be more prone to violate neoclassical assumptions? Perhaps the simplest mechanism is general intelligence. The average IQ of the poor is well below normal, which accounts for much of their earnings gap. (Herrnstein and Murray 1994, Jensen 1998) Measured intelligence also correlates negatively with illegitimacy, child abuse, smoking, and accidents (Herrnstein and Murray 1994, pp. 161-3, 179-81, 207-10, 214). All of these patterns can be plausibly interpreted as amplified departures from neoclassical assumptions.

Take illegitimacy. Herrnstein and Murray suggest the following causal model:

The smarter the woman, the more likely that she deliberately decides to have a child and calculates the best time to do it. The less intelligent the woman is, the more likely that she does not think

9. For this metaphor, we are indebted to Kevin McCabe. 
ahead from sex to procreation, does not remember birth control, does not carefully consider when and under what circumstances she should have a child. How intelligent a woman is may interact with her impulsiveness, and hence her ability to exert self-discipline and restraint on her partner in order to avoid pregnancy. (1994, p. 179)

In other words, lower intelligence amplifies judgmental biases and lack of self-control. Less intelligent women are more likely to systematically underestimate the probability of pregnancy from unprotected sex. This leads them to take risks they would avoid if they understood the true numbers. Herrnstein and Murray also appear to say that it is more difficult for them to control their own behavior; the less intelligent have a stronger tendency to make choices that they will come to regret.

Crime is another interesting case. Herrnstein and Murray acknowledge the standard human capital account of the link between low intelligence and crime: 'If, for example, people of low intelligence have a hard time finding a job, they might have more reason to commit crimes as a way of making a living' (1994, p. 240). But they also offer an alternate account based on judgmental bias:

\footnotetext{
A lack of foresight, which is often associated with low IQ, raises the attractions of the immediate gains from crime and lowers the strength of the deterrents, which come later (if they come at all). To a person of low intelligence, the threats of apprehension and prison may fade to meaninglessness. They are too abstract, too far in the future, too uncertain. (1994, p. 240)
}

Warner and Pleeter (2001) provides direct evidence that lower IQ amplifies behavioral anomalies ${ }^{10}$. During the 1990s, the U.S. military offered benefit packages to induce voluntary separation. The benefit package could be taken as an annuity or a lump-sum payment. In line with much of the behavioral literature, Warner and Pleeter find that actors use discount rates far in excess of the market interest rate - usually taken as a sign of judgmental bias, lack of selfcontrol, or both ${ }^{11}$. The present value of the lump sum was far less than the annuity - with a break-even discount rate greater than $17 \%$ - but most separatees chose the lump sum. What is noteworthy from the standpoint of the current paper is that individuals with lower measured intelligence were significantly more likely to select the lump sum. This remains true after controlling for education, experience, family size, wage, field of specialization,

10. See also the more recent contributions by Frederick (2006), and Benjamin and Shapiro (2005). Furthermore, many studies document that education - a strong correlate of both income and intelligence - reduces the magnitude of judgmental bias in a variety of subjects, including economics (Caplan 2001), politics (Delli Carpini and Keeter 1996), and toxicology (Kraus, Malmfors, and Slovic 1992).

11. There is of course a simple neoclassical explanation: credit market imperfections. The problem with this account is that the anomalies persist even if actors are definitely not liquidity constrained (e.g., they have significant home equity or other liquid assets) (Thaler 1992, pp. 119-20). 
and more. Thus, separatees' anomalous behavior becomes visibly more pronounced as their intelligence falls.

An intriguing study by Kruger and Dunning (1999) reaches the much more general conclusion that self-serving bias is decreasing in objective ability. In other words, the least competent individuals overestimate themselves the most. As Kruger and Dunning put it:

... overestimation occurs, in part, because people who are unskilled in these [social and intellectual] domains suffer a dual burden: Not only do these people reach erroneous conclusions and make unfortunate choices, but their incompetence robs them of the metacognitive ability to realize it. (p. 1121)

Since the poor are below-average on most of the standard measures of ability - including education and intelligence - we should expect their self-serving bias to be especially severe. Other research bears out this prediction. McClendon and Wigfield (1998) for example finds that in the face of poor objective performance, underachieving black children remain convinced that they are good in both math and science.

The 'culture of poverty' literature offers a (potentially complementary) alternative to Herrnstein and Murray's general intelligence story. Banfield (1968) remains an insightful introduction. Generalizing from a large ethnographic literature, Banfield identifies contrasting sets of upper, middle, working, and lower class values (1968, pp. 48-54). He argues that lower class values, transmitted from generation to generation, are an important cause of poverty. As Banfield starkly puts it:

[T] he lower-class individual lives moment to moment. If he has any awareness of the future, it is of something fixed, fated, beyond his control: things happen to him, he does not make them happen. Impulse governs his behavior, either because he cannot discipline himself to sacrifice a present for a future satisfaction or because he has no sense of the future. He is therefore radically improvident: whatever he cannot consume immediately he considers valueless. His bodily needs (especially for sex) and his taste for 'action' take precedence over everything else - and certainly over any work routine. $(1968$, p. 53)

A high discount rate may well be part of the story, but reducing it to that alone seems forced. Indeed, when Banfield elaborates, his account is almost explicitly behavioral: 'the individual's orientation toward the future will be regarded as a function of two factors: (1) ability to imagine a future, and (2) ability to discipline oneself to sacrifice present for future satisfaction' (1968, p. 47). The former strongly suggests judgmental bias; the latter, lack of selfcontrol.

Mayer's (1997) is a more recent contribution to the culture of poverty literature. She concludes that even doubling the income of the poor would have little effect on long-term poverty. Instead, the primary determinants of success are parental characteristics and attitudes, such as honesty, diligence, and 
reliability - the very attitudes Banfield maintains that the poor are lacking.

Finally, Glaeser (2006) suggests a third explanation for why the poor deviate more: the rich have more motivation and resources to make themselves rational:

\begin{abstract}
But there are many reasons to think that incentive effects will be much stronger in the real world than in the laboratory. In experiments, individuals have few tools with which to improve their reasonings, and their only real method of responding to incentives is to think harder. Outside of the lab, people have access to advisers, books, the Internet, and more time. Their willingness to spend time and money to use these resources will surely depend on the stakes involved in the decision. (2006, p. 140)
\end{abstract}

Since the rich have both higher stakes and more resources, Glaeser's analysis predicts that their choices will be more rational (though admittedly, their higher opportunity cost of time cuts the other way).

\title{
V. POLICY IMPLICATIONS
}

Moral hazard is the traditional neoclassical argument for limiting government assistance. As programs become more generous, behavioral distortions increase. Ultimately, the marginal dollar transferred costs donors much more than a dollar, so if you put any weight on donors' welfare, there comes a point when you say 'enough.' The behavioral perspective advises us to superimpose further costs onto this calculus: We must consider the cost to the recipients as well as the cost to the donors. Once we acknowledge that the disadvantaged not only deviate from neoclassical assumptions, but deviate to an unusually strong degree, there are at least arguably expansive implications for policy. Behavioral issues do not trump all other considerations, but they do push us in certain directions.

Most obviously, if government assistance to the disadvantaged amplifies the ill effects of their judgmental biases and self-control problems, it strengthens the case for reducing the size of welfare benefits, limiting their duration, restricting eligibility, and even abolition. The more 'generous' programs are, the more likely they are to harm their ostensible beneficiaries further down the road. But due to self-control problems, many people will accept the benefits anyway. They are just too tempting to turn down. Moreover, recipients will generally overestimate their own ability to pursue their long-run interests while on the dole: 'Other people may live in the present and grow increasingly unemployable, but not me.' 'Other single moms may be unable to care for their children and pursue a career, but not me.'

Behavioral economics also puts affirmative action in a new light. If students overestimate their own academic abilities, you could help the 'beneficiaries' of 
Figure 2

Deviations from Neoclassical Assumptions and Optical Policy

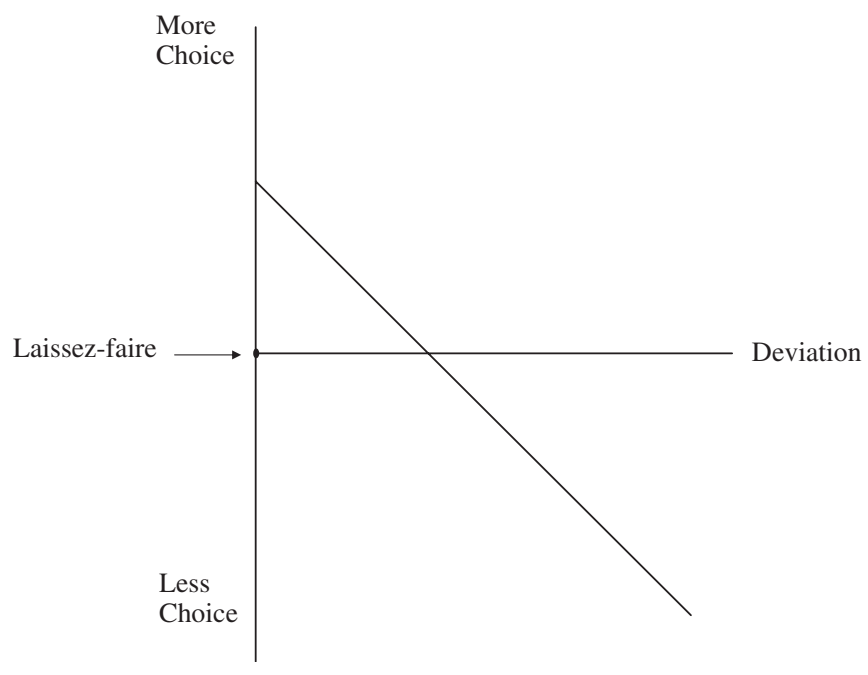

affirmative action by curtailing or ending preferential admissions. Even in the absence of affirmative action, self-serving bias leads students to pursue overly risky academic strategies: 'Other kids may get in over their heads, but not me.' Expanding their set of risky choices with preferential admissions makes the problem worse. While this is not an ironclad argument against affirmative action, it is an additional cost of the policy that most analyses neglect.

Neoclassical economics would have to label our reasoning 'paternalistic.' As Sunstein $(2000$, p. 46$)$ observes, behavioral economics is at least 'anti-antipaternalist.' It opens up the possibility of hurting people by expanding their choice set, and helping them by shrinking their choice set.

This theoretical result is plainly symmetric. If expanding labor market choices above the laissez-faire level makes the poor worse off, then reducing them below the laissez-faire level might make the poor better off still. One might interpret laws against vagrancy or truancy in this light - as an attempt to correct for agents' self-control problems when they weigh the benefits of leisure today against the future benefits of human capital acquisition.

Imagine graphing socially optimal policy as a function of the severity of agents' deviation from neoclassical assumptions (Figure 2). For mild deviations, the optimal adjustment would presumably only be to slightly curtail the generosity of government assistance. As deviations from neoclassical assumptions becomes greater, though, the long-run harm of a given level of assistance rises, and the optimal level of generosity accordingly falls. For severe biases, 
Figure 3

Deviations from Neoclassical Assumptions and Optical Policy with Fixed Costs

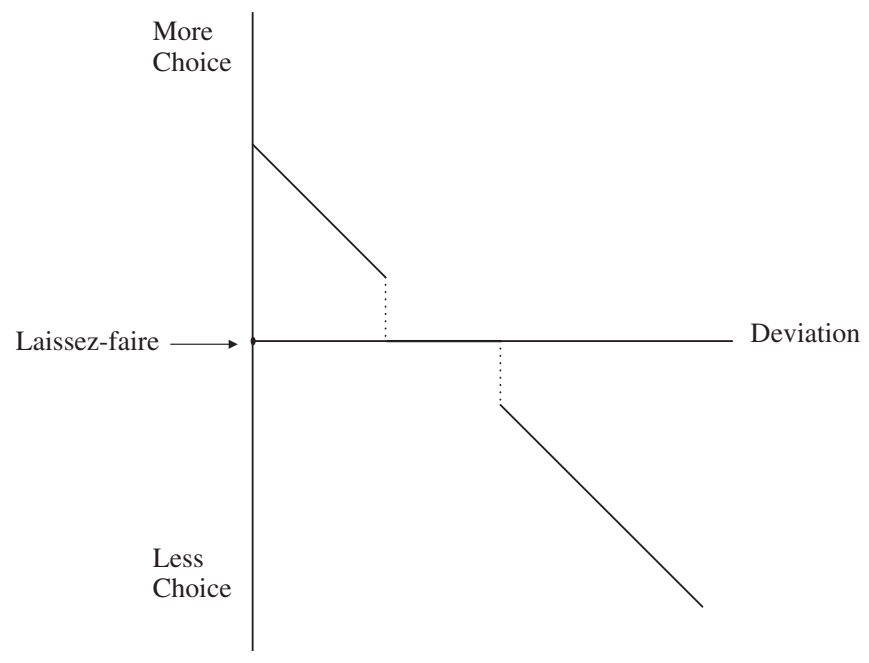

simple refusal to help will not suffice, and optimal policy would have to restrict even the choice set remaining to the poor under laissez-faire.

So the behavioral perspective definitely argues for different government policies, but not necessarily for less government. There is however a contingent factor that pushes in favor of laissez-faire: the fixed costs of government programs. As long as any form of intervention - whether positive (e.g. giving the poor money) or negative (e.g. forbidding vagrancy) - has fixed costs, there exists a discrete range over which laissez-faire is optimal (Figure 3). If, ignoring fixed costs, the optimal policy involves only mild government action, then taking fixed costs into account, the optimal policy is no government action at all ${ }^{12}$.

Thus, there is a contingent connection between behavioral economics and conservative and libertarian pleas for laissez-faire. At the same time, the behavioral approach pushes against laissez-faire along other policy dimensions. Consider regulation of drugs, alcohol, and tobacco. From a standard neoclassical perspective, consumption of these substances is an unambiguous social benefit. The textbook case for restriction or prohibition therefore hinges

12. To this extent, we share Glaeser's (2006) conclusion that 'recognizing the limits of human cognition may strengthen the case for limited government' (p. 133). But our arguments are almost orthogonal. We use behavioral economics to undermine neoclassical economics' analysis of the welfare state. Glaeser uses behavioral political economy to undermine behavioral economics' analysis of paternalism. 
on externalities - externalities which many economists have called into question. The standard rationale for taxes on cigarettes, for instance, is that smokers do not pay the full social cost of their habit because government picks up a share of their medical expenses (Grossman et al. 1993, Hay 1991, Manning et al. 1989, 1991). This argument has been debunked by economists who point out that smokers also die younger, and that the savings from earlier death outweigh the costs of smoking-related medical treatments (Viscusi 1994).

From a behavioral perspective, one can construct a quite different case for taxes on tobacco. We must consider not just the costs smokers impose on nonsmokers, but also the costs that smokers impose on themselves. Smokers often lament that lack of self-control prevents them from kicking their habit (Survanovic et al. 1999, Wertenbroch 1998, Akerlof 1991, Winston 1980). Overconfidence arguably exacerbates their plight: young smokers may form a plan to quit when they turn forty, thinking 'Unlike others, $I$ can stop anytime I want.' Using taxes to raise the price of cigarettes could therefore actually help smokers. By increasing the upfront cost of the habit, you could make them 'act as if' they accurately adjusted for its long-term consequences.

Moreover, insofar as the poor suffer from more pronounced biases than other segments of the population, what is usually seen as a defect of cigarette taxes - their regressive impact - is actually a benefit! The more severe people's deviation from neoclassical assumptions, the larger the gap between their choices and their welfare. A constant per-pack tax presumably matters more to low-income smokers. Thus, cigarette taxes probably have the largest effect on the tobacco consumption of those who, left to their own devices, tend to do themselves the most harm.

To repeat, behavioral considerations do not trump conventional neoclassical cost-benefit analysis. One could admit that consumers of heroin would generally be better off consuming no heroin, but still reject the efficiency case for prohibition by pointing to indirect effects of street violence and adulteration. What the behavioral perspective teaches us is that the standard neoclassical framework neglects some of the benefits of prohibition. Whether or not these forgotten benefits tip the scales depends on how close the contest was to begin with.

It is wise to pursue paternalistic reasoning cautiously (Glaeser 2006). There is a risk of redefining all behaviors you disapprove of as 'self-control problems,' and all beliefs you disagree with as 'judgmental biases.' The danger you pose to yourself is probably trivial compared to the danger of living under the veto of a randomly selected behavioral economist. A risk-averse policy-maker should think long and hard before directly ordering the poor about for their own good. But curtailing the generosity of existing programs is a low-risk, straightforward way to modify policy to take account of behavioral concerns. 
Incidentally, our analysis is equally relevant for private charity. Concerned altruists have to consider the possibility that less fortunate would be better off if they helped them less. This suggests a new spin on the long-standing distinction between the 'deserving' and the 'undeserving' poor (Himmelfarb 1991). You might conceive of the deserving poor as those who are clearheaded and disciplined enough to benefit from financial assistance. The undeserving poor, conversely, can be seen as those too far from the rational actor model to mechanically benefit from higher income. Philanthropists with 'hard heads and soft hearts' - to use Alan Blinder's (1987) phrase - must face the harsh reality that they may be unable to help those who will not help themselves.

\section{CONCLUSION}

To the best of our knowledge, this is the first paper to analyze the connection between behavioral economics and what Tyler Cowen calls the 'traditional conservative critique of the welfare state.' Most detractors of the welfare state have turned to neoclassical economics for intellectual support. Few promoters of behavioral economics have stopped to consider its implications for poverty policy.

Our paper aims to reverse both of these trends. Some of the most common complaints about the welfare state are, from a strict neoclassical perspective, senseless. But from the standpoint of behavioral economics, they are quite coherent. Moreover, even though behavioral economists have given policy towards the disadvantaged short shrift, this turns out to be a topic where behavioral findings are especially relevant. A variety of sources indicate that 'the poor deviate more.' If the average person violates neoclassical assumptions, the average welfare recipient violates them to a markedly greater degree.

Some of the policy implications are straightforward: behavioral economics provides additional reasons for less generous government assistance along a number of margins. If the people the government wants to help do not fully account for the negative long-run effects of accepting help, they are better off if the government does the accounting for them. Other policy implications are less obvious. Specifically, it is theoretically possible for government to help the disadvantaged by reducing their choice set below the laissez-faire level. The traditional conservative critique of the welfare state is fundamentally paternalist. Once you accept the idea that you can hurt people by giving them more choices, you cannot dismiss the idea that you can help them by taking some of their choices away. In practice, of course, the latter is much more costly and intrusive than the former (Glaeser 2006). 
There are important implications for future research. The behavioral literature has documented that the average person frequently violates neoclassical assumptions. But it rarely investigates variation in the tendency to violate neoclassical assumptions ${ }^{13}$. Casual empiricism and limited formal evidence suggest that the poor do deviate more. A great deal more could be learned at low cost if new behavioral studies collected information on participants' income and education to test for heterogeneity.

One of the main contributions of behavioral economics has been to subject the fundamental assumptions of economic theory to empirical scrutiny. Textbook micro is useful in a great many contexts, but behavioral economists have found some blind spots. In this paper, we have argued that common sense doubts about the efficacy of the welfare state are often isomorphic to some of the main blind spots behavioral economists have discovered. On a homework problem in intermediate micro, you can eliminate poverty with lump-sum transfers. In the real world, matters are not so simple.

\section{REFERENCES}

Akerlof, George A. (2002). Behavioral Macroeconomics and Macroeconomic Behavior, American Economic Review. 92: 411-33.

Akerlof, George A. (1991). Procrastination and Obedience, American Economic Review. 81(2): 1-19.

Banfield, Edward C. (1968). The Unheavenly City. Boston: Little, Brown and Co.

Benjamin, Daniel and William Dougan (2001). Individuals' Estimates of the Risks of Death: Part IINew Evidence, Journal of Risk and Uncertainty. 33-57.

Benjamin, Daniel and William Dougan (1997). Individuals' Estimates of the Risks of Death: Part IA Reassessment of Previous Evidence, Journal of Risk and Uncertainty. 115-33.

Benjamin, Daniel and Jesse Shapiro (2005). Who is 'Behavioral'? Cognitive Ability and Anomalous Preferences. unpub. ms. http://home.uchicago.edu/ jmshapir/iq070405.pdf.

Bertrand, Marianne, Sendhil Mullainathan and Eldar Shafir (2004). A Behavioral-Economics View of Poverty, American Economic Review. 94: 419-423.

Blinder, Alan (1987). Hard Heads, Soft Hearts: Tough-Minded Economics for a Just Society. Reading, MA: Addison-Wesley.

Camerer, Colin and Richard H. Thaler (1995). Anomalies: Ultimatums, Dictators, and Manners, Journal of Economic Perspectives. 9: 209-19.

Caplan, Bryan (2001). What Makes People Think Like Economists? Evidence on Economic Cognition from the Survey of Americans and Economists on the Economy, Journal of Law and Economics. 44: 395-426.

Chavez, Linda (2002). An Unlikely Conservative. New York: Basic Books.

Chavez, Linda (1992). Out of the Barrio: Toward a New Politics of Hispanic Assimilation. New York: Basic Books.

Cowen, Tyler (2002). Does the Welfare State Help the Poor?, Social Philosophy and Policy. 19: $36-54$.

13. For notable exceptions, see Frederick (2006), Benjamin and Shapiro (2005), and Warner and Pleeter (2001). 
Cutler, David, Edward Glaeser and Jesse Shapiro (2003). Why Have Americans Become More Obese?, Journal of Economic Perspectives. 17: 93-118.

Delli Carpini, Michael X, and Scott Keeter (1996). What Americans Know About Politics and Why It Matters. New Haven, CT: Yale University Press.

Frederick, Shane (2006). On the Ball: Cognitive Reflection and Decision Making. unpub. ms. http:// www.mit.edu/people/shanefre/On\%20the \% 20Ball.pdf.

Frey, Bruno and Eichenberger, Reiner (1994). Economic Incentives Transform Psychological Anomalies, Journal of Economic Behavior and Organization. 23: 215-34.

Frey, Bruno and Eichenberger, Reiner (1989a). Anomalies and Institutions, Journal of Institutional and Theoretical Economics. 145: 423-437.

Frey, Bruno and Eichenberger, Reiner (1989b). Should Social Scientists Care about Choice Anomalies?, Rationality and Society. 1: 101-122.

Friedman, Milton (1982 [1962]). Capitalism and Freedom. Chicago: University of Chicago Press.

Glaeser, Edward (2006). Paternalism and Psychology, University of Chicago Law Review. 73: $133-156$.

Grossman, Michael, Jody L. Sindelar, John Mullahy and Richard Anderson (1993). Policy Watch: Alcohol and Cigarette Taxes, Journal of Economic Perspectives. 7: 211-22.

Haley, Alex and Malcolm X (1999 [1964]). The Autobiography of Malcolm X. New York: Random House.

Harlow, Caroline W. 1998. Bureau of Justice Statistics Special Report: Profile of Inmates 1996. U.S. Department of Justice. URL http://www.ojp.usdoj.gov/bjs/pub/pdf/pji96.pdf.

Hay, Joel W. (1991). The Harm They Do to Others: A Primer on the External Costs of Drug Abuse, in: Melvyn B. Krauss and Edward P. Lazear (eds.), Searching for Alternatives: Drug Control Policy in the United States. Stanford, CA: Hoover Institution Press.

Herrnstein, Richard J. and Charles Murray (1994). The Bell Curve: Intelligence and Class Structure in American Life. New York: Free Press.

Himmelfarb, Gertrude (1991). Poverty and Compassion: The Moral Imagination of the Late Victorians. New York: Knopf.

Kahneman, Daniel, Jack L. Knetsch and Richard H. Thaler (1990). Experimental Tests of the Endowment Effect and the Coase Theorem, Journal of Political Economy. 98: 1325-48.

Kahneman, Daniel, Paul Slovic and Amos Tversky eds. (1982). Judgment Under Uncertainty: Heuristics and Biases. New York: Cambridge University Press.

Kahneman, Daniel and Amos Tversky (1982). On the Study of Statistical Intuitions, in: Daniel Kahneman, Paul Slovic and Amos Tversky (eds.) Judgment Under Uncertainty: Heuristics and Biases. New York: Cambridge University Press.

Kahneman, Daniel and Amos Tversky (1979). Prospect Theory: An Analysis of Decision Under Risk, Econometrica. 47: 263-91.

Kirby, Kris and Herrnstein, Richard J. (1995). Preference Reversals Due to Myopic Discounting of Delayed Reward, Psychological Science. 6: 83-9.

Kraus, Nancy, Torbjörn Malmfors and Paul Slovic (1992). Intuitive Toxicology: Expert and Lay Judgments of Chemical Risks, Risk Analysis. 12: 215-32.

Kruger, Justin and David Dunning (1999). Unskilled and Unaware of It: How Difficulties in Recognizing One's Own Incompetence Lead to Inflated Self-Assessments, Journal of Personality and Social Psychology. 77: 1121-34.

Laibson, David (1998). Life-Cycle Consumption and Hyperbolic Discount Functions, European Economic Review Papers and Proceedings. 42: 861-71.

Laibson, David (1997). Golden Eggs and Hyperbolic Discounting, Quarterly Journal of Economics. 112(2): 443-78.

Laibson, David, Andrea Repetto and Jeremy Tobacman (1998). Self-Control and Saving for Retirement, Brookings Papers on Economic Activity. 1: 91-196. 


\section{SCOTT BEAULIER/BRYAN CAPLAN}

Levitt, Steven and Stephen Dubner (2006). Freakonomics: A Rogue Economist Explores the Hidden Side of Everything. New York: HarperCollins.

Manlove, Jennifer, Elizabeth Terry, Laura Gitelson, Angela Romano Papillo and Stephen T. Russell (2000). Explaining Demographic Trends in Teen Fertility, 1980-1995: The Changing Context of Adolescence, Family Planning Perspective. 32: 166-75.

Manning, Willard, Emmett Keeler, Joseph P. Newhouse, Elizabeth Sloss and Jeffrey Wasserman (1991). The Costs of Poor Health Habits. Cambridge: Harvard University Press.

Manning, Willard, Emmett Keeler, Joseph P. Newhouse, Elizabeth Sloss and Jeffrey Wasserman (1989). The Taxes of Sin: Do Smokers and Drinkers Pay Their Way?, Journal of American Medical Association. 261: 1604-1609.

Mayer, Susan E. (1997). What Money Can't Buy: Family Income and Children's Life Chances. Cambridge, MA: Harvard University Press.

McClendon, Crystal and Allan Wigfield (1998). Group Differences in African American Adolescents' Achievement-Related Beliefs about Math and Science: An Initial Study, Journal of Black Psychology. 24: 28-43.

Murray, Charles A. (1984). Losing Ground: American Social Policy, 1950-1980. New York: Basic Books.

National Household Survey on Drug Abuse (2002). http://www.samhsa.gov/. Office of Applied Studies, Washington, DC.

National Survey of Family Growth (1996). http://nichd.nih.gov. National Institute of Child Health and Human Development, Bethesda, MD.

O’Donoghue, Ted and Matthew Rabin (2003). Self Awareness and Self Control, in: Roy F. Baumeister, George Lowenstein and Daniel Read (eds.) Time and Decision: Economic and Psychological Perspectives on Intertemporal Choice. Russell Sage Foundation: 217-244.

O'Donoghue, Ted and Matthew Rabin (1999a). Doing It Now or Later, American Economic Review. 89: 103-24.

O’Donoghue, Ted and Matthew Rabin (1999b). Incentives for Procrastinators, Quarterly Journal of Economics. 114: 769-816.

Pesaran, Hashem (1987). The Limits to Rational Expectations. Oxford: Blackwell.

Rabin, Matthew (1998). Psychology and Economics, Journal of Economic Literature. 36: 11-46.

Rothbard, Murray N. (1978). For a New Liberty: The Libertarian Manifesto. New York: Libertarian Review Foundation.

Sheffrin, Steven M. (1996). Rational Expectations. Cambridge: Cambridge University Press.

Sowell, Thomas (1996 [1980]). Knowledge and Decisions. New York: Basic Books.

Sowell, Thomas (1993). Inside American Education: The Decline, the Deception, the Dogmas. New York: Free Press.

Sowell, Thomas (1990). Preferential Policies: An International Perspective. New York: W. Morrow. Sowell, Thomas (1987). Compassion Versus Guilt, and Other Essays. New York: W. Morrow.

The Substance Abuse and Mental Health Service Administration. (1997). http://www.samhsa.gov Office of Applied Studies, Washington, DC.

Sucoff, Clea A. and Dawn M. Upchurch (1998). Neighborhood Context and the Risk of Child Bearing Among Metropolitan Area Black Adolescents, American Sociological Review. 63: 571-85.

Sunstein, Cass R. (1996). Social Norms and Social Roles, Columbia Law Review. 96: 903-68.

Sunstein, Cass R. ed. (2000). Behavioral Law and Economics. New York: Cambridge University Press.

Survanovic, Steven M., Robert S. Goldfarb and Thomas C. Leonard (1999). An Economic Theory of Cigarette Addiction, Journal of Health Economics. 18: 1-29.

Thaler, Richard H. (1992). The Winner's Curse: Paradoxes and Anomalies of Economic Life. Princeton: Princeton University Press. 
Thaler, Richard H. and Eric J. Johnson (1990). Gambling with the House Money and Trying to Break Even: Effects of Prior Outcomes on Risky Choice, Management Science. 36: 643-60.

Thaler, Richard H. and Hersh M. Shefrin (1981). An Economic Theory of Self-Control, Journal of Political Economy. 89: 392-406.

Viscusi, W. Kip (1996). Rational Risk Policy. New York: New York University Press.

Viscusi, W. Kip (1994). Cigarette Taxation and the Social Consequences of Smoking, National Bureau of Economic Research Working Paper. No. 4891.

Viscusi, W. Kip (1992). Fatal Tradeoffs: Public and Private Responsibilities for Risk. New York: Oxford University Press.

Viscusi, W. Kip (1987). Learning about Risk: Consumer and Worker Responses to Hazard Information. Cambridge, MA: Harvard University Press.

Warner, John T. and Saul Pleeter (2001). The Personal Discount Rate: Evidence from Military Downsizing Programs, American Economic Review. 91: 33-53.

Weinstein, Neil D. (1989). Optimistic Biases about Personal Risks, Science. 1232.

Wertenbroch, Klaus (1998). Consumption Self-Control by Rationing Purchase Quantities of Virtue and Vice, Marketing Science. 17: 317-37.

Wilson, William J. (1996). When Work Disappears. New York: Random House.

Winston, Gordon C. (1980). Addiction and Backsliding: A Theory of Compulsive Consumption, Journal of Economic Behavior and Organization. 1: 295-324.

\section{SUMMARY}

Critics often argue that government poverty programs perversely make the poor worse off by encouraging unemployment, out-of-wedlock births, and other 'social pathologies.' However, basic microeconomic theory tells us that you cannot make an agent worse off by expanding his choice set. The current paper argues that familiar findings in behavioral economics can be used to resolve this paradox. Insofar as the standard rational actor model is wrong, additional choices can make agents worse off. More importantly, existing empirical evidence suggests that the poor deviate from the rational actor model to an unusually large degree. The paper then considers the policy implications of our alternative perspective. 
Copyright of Kyklos is the property of Blackwell Publishing Limited and its content may not be copied or emailed to multiple sites or posted to a listserv without the copyright holder's express written permission. However, users may print, download, or email articles for individual use. 